\title{
ASSOCIATION OF LOW BACK PAIN AND SCIATICA WITH SIGNAL CHANGES IN THE VERTEBRAL ENDPLATE
}

\author{
ASSOCIAÇÃO DA DOR LOMBAR E CIÁTICA A ALTERAÇÕES DE IMAGEM NA PLACA \\ VERTEBRAL TERMINAL
}

\section{ASOCIACIÓN DEL DOLOR LUMBAR Y CIÁTICO CON ALTERACIONES DE IMAGEN EN LA PLACA VERTEBRAL TERMINAL}

Alberto Ofenhejm Gotfryd, ${ }^{1,2,3}$ Déllo Eulálo Martins Filmo, ${ }^{1,2,3}$ Marcelo Wajchenberg, ${ }^{1,2,3}$ Michel Kanas, ${ }^{1,2,3}$ Saulo de Tarso de Sá Pereira Segundo, $1,2,3$ Yuri Pereira GeleLAIte ${ }^{1,2,3}$

1. Hospital Israelita Albert Einstein, São Paulo, SP, Brazil.

2. Albert Einstein Instituto Israelita de Ensino e Pesquisa, São Paulo, SP, Brazil.

3. Albert Einstein Instituto Israelita de Ensino e Pesquisa, Locomotor Program, São Paulo, SP, Brazil.

\begin{abstract}
Objective: To evaluate whether vertebral endplate signal changes (VESCs) influence the prognosis of patients submitted to conservative or surgical treatment for low back pain and lumbosciatica. Methods: Study with 241 patients who underwent conservative treatment, infiltration or surgery with 12 months of follow-up. They were evaluated for pain by the Visual Analog Scale for Pain (VAS), for function by the Roland Morris questionnaire and for quality of life by the EuroQol5 (EQ-5D). Results: The VESCs did not have a significant effect on the treatment responses for the VAS $(F=0.03 ; P=0.97)$, Roland Morris $(F=0.51 ; P=0.60)$ and $E Q-5 D(F=2.67 ; P=0.07)$ variables, nor was there any interaction between VESC and treatment for VAS $(F=2.15 ; P=0.08)$, Roland Morris $(F=1.55 ; P=0.19)$ and $E Q-5 D$ $(F=2.15 ; P=0.08)$. There was a significant effect for all treatments, however, the effect of the surgical procedure was superior when compared to the others ( $P<0.001)$. The VESC frequency was $48.33 \%$ for type $0,29.17 \%$ for type I and $22.50 \%$ for type II. Conclusions: The presence of VESC and its different types is not associated with a worse prognosis, nor was a higher prevalence of VESC observed in the patients with low back pain and lumbosciatica. Level of Evidence II; Retrospective cohort study.
\end{abstract}

Keywords: Vertebral End-Plate Signal Changes; Low Back Pain; Sciatica; Surgery; Conservative Treatment.

\section{RESUMO}

Objetivo: Avaliar se as alterações de sinal do platô vertebral (ASPV) influenciam o prognóstico de pacientes submetidos ao tratamento conservador ou cirúrgico em lombalgia e lombociatalgia. Métodos: Estudo com 241 pacientes submetidos ao tratamento conservador, infiltração ou cirurgia, com acompanhamento de 12 meses. Foram avaliados pela Escala Visual Analógica (EVA) da Dor, quanto à função, pelo questionário Roland Morris e quanto à qualidade de vida, pelo questionário EuroQol5 (EQ-5D). Resultados: As ASPV não tiveram efeito significante nas respostas do tratamento para as variáveis $E V A(F=0,03 ; P=0,97)$, Roland Morris $(F=0,51 ; P=0,60)$ e $E Q-5 D(F=2,67$; $P=0,07)$, bem como não houve interação de ASPV e tratamento para EVA $(F=2,15 ; P=0,08)$, Roland Morris $(F=1,55 ; P=0,19)$ e $E Q-5 D(F=2,15 ; P=0,08)$. Houve efeito significante para todos os tratamentos; entretanto, o efeito do procedimento cirúrgico foi superior quando comparado aos demais ( $P<0,001)$. A frequência de ASPV tipo 0 foi 48,33\%, tipo I foi 29,17\% e tipo II foi 22,50\%. Conclusões: A presença de ASPV e seus diferentes tipos não estão associados a prognóstico pior, bem como não se demonstrou maior prevalência de ASPV nos pacientes com lombalgia e lombociatalgia. Nível de Evidência II; Estudo de coorte retrospectivo.

Descritores: Alterações de Sinal do Platô Vertebral; Lombalgia; Ciática; Cirurgia; Tratamento Conservador.

\section{RESUMEN}

Objetivo: Evaluar si las alteraciones de señal de la meseta vertebral (ASMV) influyen en el pronóstico de los pacientes sometidos a tratamiento conservador o quirúrgico en lumbalgia y lumbociatalgia. Métodos: Estudio con 241 pacientes sometidos al tratamiento conservador, infiltración o cirugía, con acompañamiento de 12 meses. Se evaluaron a través de la Escala Visual Analógica del Dolor (EVA), cuanto a la función, por el cuestionario Roland Morris y cuanto a la calidad de vida por el cuestionario EuroQol5 (EQ-5D). Resultados: Las ASMV no tuvieron efecto significativo en las respuestas del tratamiento para las variables $E V A(F=0,03 ; P=0,97)$, Roland Morris $(F=0,51 ; P=0,60)$ y $E Q-5 D(F=2,67 ; P=0,07)$, así como no hubo interacción de $A S M V$ y tratamiento para $E V A(F=2,15 ; P=0,08)$, Roland Morris $(F=1,55$; $P=0,19)$ y $E Q-5 D(F=2,15 ; P=0,08)$. Hubo efecto significativo para todos los procedimientos, entretanto, el efecto del procedimiento quirúrgico fue superior cuando comparado a los demás ( $P<0,001)$. La frecuencia de ASMV para el tipo 0 fue 48,33\%, tipo I 29,17\% y tipo II 22,50\%. Conclusiones: La presencia de ASMV y sus diferentes tipos no están asociados a pronóstico peor, bien como no se demostró mayor prevalencia de ASMV en los pacientes con lumbalgia y lumbociatalgia. Nivel de Evidencia II; Estudio de cohorte retrospectivo.

Descriptores: Cambios en la Señal de la Placa Vertebral; Dolor de la Región Lumbar; Ciática; Cirugía; Tratamiento Conservador. 


\section{INTRODUCTION}

Low back pain is one of the most common complaints in the emergency room. About $70 \%$ to $85 \%$ of the population experiences low back pain at least once in their life, with an annual prevalence of $15 \%$ to $45 \%$. ${ }^{1}$ Most cases of low back pain have a good prognosis with improved symptoms in around 8 weeks and with a recovery rate of $95 \%$ in a few months. It occurs most often in adults, equally distributed between men and women. ${ }^{2}$

Low back pain is the primary cause of functional impairment in healthy individuals under 45 years of age, the second most common hospital complaint and the main cause of work absence, being responsible for $85 \%$ of cases. Two thirds of the costs are indirect, due to low productivity and loss of days worked..$^{1,2}$

In 1988, Modic et al. evaluated 474 individuals with chronic low back pain and classified degenerative changes of the vertebral endplate into three types, in accordance with the magnetic resonance (MR) findings. ${ }^{3}$ Type 0 is a vertebral endplate without changes. Type I was characterized as an isosignal in T1-weighted images and a hypersignal in T2-weighted images. It was attributed to edema of the subchondral bone and medulla, associated with hypervascularization. Type II shows a hypersignal in T1 and an isosignal or slight signal increase in T2-weighted images, which is attributed to the substitution of bone marrow by fatty tissue and is associated with a chronic process. ${ }^{3}$ Type III was added later, describing lesions with a hyposignal in T1 and T2, suggesting an advance of the inflammatory process with subsequent sclerosis of the subchondral bone. ${ }^{4}$

The prevalence of vertebral endplate signal changes (VESC) is unclear, varying by age and group studied. ${ }^{5}$ A number of studies and narratives have linked VESC to specific low back pain (spondylitis, trauma, tumors and spondyloarthropathies).$^{6}$ A relationship between VESC and non-specific low back pain was also found. ${ }^{7}$ This association has already been investigated by several studies, being correlated inconsistently with the relationship between these factors varying from low to high. In a systematic review, Jensen et al. found a positive correlation between VESC and non-specific low back pain in 7 of 10 articles and concluded that VESC is a common change in individuals with non-specific low back pain, but that may be present in asymptomatic individuals.

Degenerative changes found in MR images are common in asymptomatic individuals. In the fifth decade of life, around $25 \%$ of the asymptomatic population has MR degenerative changes. ${ }^{8}$ Above 60 years of age, these changes are present in $75 \%$ of the population, regardless of symptomatology. ${ }^{9}$

The objective of this study is to evaluate whether changes of the vertebral endplate signal (observed in MR using the Modic classification) influence the prognosis of patients with low back pain and lumbosciatica submitted to conservative treatment or surgery and to try to observe what type of alteration is the most common in each group of patients.

\section{METHODS}

This was a retrospective cohort study, approved by the Institutional Review Board (09625519.8.0000.0071), in which the medical records and imaging examinations of patients treated surgically or not for low back pain and sciatica during the period from May 2011 to March 2017 were evaluated. The patients signed the Informed Consent Form. The VESCs found in the imaging examinations (MR) along with the level of pain, limitation, quality of life and function were evaluated at the beginning and after 12 months of follow-up.

MR images from the institution's database obtained at the time of the inclusion of the patient in the program using a Tesla 1.5 device were used. T1- and T2-weighted sagittal and axial images were used to classify changes according to Modic. These examinations were evaluated by a radiologist from the institution and the image characteristics followed the recommendations of the Combined Task Force of the North American Spine Society, the American Society of Spine Radiology and the American Society of Neuroradiology. ${ }^{8}$ The levels used in the study were L3-L4, L4-L5 and L5-S1.
Per protocol in our hospital, the patient's pain status, quality of life and functional status are evaluated at the time of inclusion of the patient in the treatment and at 12 months following conservative or surgical treatment. For inclusion in this study, the patient must have completed the following scales:

Pain, via the Visual Analog Scale for Pain (VAS). The score ranges from 0 to 10, 0 being the absence of pain and 10 incapacitating pain, from 1 to 3 is considered mild pain, from 4 to 6 moderate pain and from 7 to 10 intense pain. Variations of at least 2.6 points are clinically significant. ${ }^{10}$

Function via the Roland Morris questionnaire validated for Portuguese, a questionnaire with 24 items that evaluate the function/ limitation of the patient, zero being without disability and 24 being severely disabled. Scores greater than 14 points indicate physical disability. Differences of 5 points are clinically significant. ${ }^{10,11}$

Quality of life using the EuroQoL5 (EQ-5D) questionnaire validated for Portuguese, a standardized questionnaire filled out by the patient in which there are 5 items: mobility, self-care, habitual activities, pain/discomfort, and anxiety/depression. Variations of at least 0.24 points are considered clinically significant. ${ }^{10}$

\section{Population of Interest and Eligibility}

The population of interest was made up of patients treated for low back pain and lumbosciatica, submitted or not to surgery, through the Locomotor Program of the Hospital Israelita Albert Einstein during the period from May 2011 to March 2017.

Patients with arthrodesis, previous surgery, tumors, infection, scoliosis greater than $10^{\circ}$, spondyloarthropathies and patients over 65 years of age were excluded.

\section{Statistical Analysis}

Data normality was evaluated using Shapiro-Wilk and the homogeneity of variance using the Levene test. Absolute and relative frequencies were quantified for degenerative alterations in the vertebral endplate according to the Modic classification.

General univariate linear models were used to compare the effects of the procedures (conservative, infiltration, and surgery) considering the Modic classifications (type 0, type I and type II). As such, the effect of the procedure was calculated for the variables VAS, Roland Morris and EQ-5D as the difference between post-intervention and pre-intervention scores and inserted into the models as dependent variables. Since the groups presented differences in the dependent variables at the baseline, these variables were inserted as covariables. The type of treatment was inserted as a fixed factor and to test the effect of the Modic type and age on responses to the treatment a VESC* interaction treatment and age* interaction treatment were inserted into the models. In addition, a general univariate linear model was created to evaluate the effect of the classification of the VESCs on the deltas of post-pre difference on the independent variables (VAS, Roland Morris and EQ-5D) in each procedure (conservative, infiltration and surgical). One-way analysis of variance (ANOVA) was used to compare the age of the participants when separated into different classifications according to Modic. The significance adopted was $\mathrm{P}<0.05$. The procedures were analyzed in SPSS software (version 20).

\section{RESULTS}

A total of 1677 medical records were obtained from the database, being reduced to 1305 after exclusion of cases with associated neck pain. Of the remaining medical records, we observed that 892 had no examinations in the hospital imaging system, 35 had undergone some previous surgical procedure, 126 had not completed the questionnaire after 12 months and 11 were over 65 years of age. The total number of patients obtained was 241.

After statistical analysis, it was observed that the procedures had statistically significant effects on the VAS, Roland Morris and EQ-5D variables, however, the VESCs did not have a significant effect on the treatment responses for the variables VAS $(F=0.03$; 
$P=0.97)$, Roland Morris $(F=0.51 ; P=0.60)$ and $E Q-5 D(F=2.67$; $P=0.07)$, nor was there any VESC*treatment interaction for VAS $(F=2.15 ; P=0.08)$, Roland Morris $(F=1.55 ; P=0.19)$ and $E Q-5 D$ $(F=2.15 ; P=0.08)$, even when the groups were separated by Modic's classification and analyzed independently within each procedure: VAS: Conservative $F=0.93, P=0.40$; Infiltration: $F=1.83$, $P=0.17$; Surgical: $F=1.71, P=0.19$; Roland Morris: Conservative: $F=0.47, P=0.63$; Infiltration: $F=2.18 ; P=0.12$, Surgical: $F=0.12 ; P=0.89 ; E Q-5 D$ : Conservative: $F=0.31 ; P=0.73$, Infiltration: $P=0.08$, Surgical: $F=1.05 ; P=0.36$. (Tables 1,2 and 3 )

One-way ANOVA showed that the mean age of the participants was different among the Modic groups $(F=3.12 ; P=0.046)$. The Bonferroni post-hoc test identified an age difference between the Modic 0 and Modic II groups (41.75 \pm 11.66 years vs. $46.40 \pm$ 11.07 years). There was no age difference between the Modic I group and the other groups (44.15 \pm 11.95 years). Although there was a difference between the Modic groups in relation to age, the inclusion of age had no influence on the effects of treatments on VAS $(F=0.90 ; P=0.66)$ and Roland Morris $(F=0.96 ; P=0.56)$ variables.

The deltas of the post-pre difference for pain assessed by the visual analog scale (VAS) are shown in Table 4. There were significant effects $(P<0.001)$ for all the procedures; however, the effect of the surgical procedure was greater than the others $(P<0.001)$.

The post-pre difference deltas for the Roland Morris scale are presented in Table 5. There were significant effects $(P<0.001)$ for all procedures; however, the effect of the surgical procedure was superior as compared to the others $(P<0.001)$.

The deltas of the post-pre difference for EQ-5D are shown in Table 6. There were significant effects $(P<0.001)$ for all the procedures; however, the effect of the surgical procedure was superior when compared to the others $(P<0.001)$.

The number and percentage of patients in the different Modic classifications are presented in Table 7.

\section{DISCUSSION}

Magnetic resonance is the main diagnostic examination used in patients with low back pain and sciatica. ${ }^{12}$ VESCs may be present in the cervical, thoracic and lumbar spines, having even been documented in animal studies. ${ }^{13}$ The prevalence ranges from
Table 4. Delta of difference in pain evaluated by the visual analog scale (VAS) for the Infiltration, Conservative and Surgical procedures.

\begin{tabular}{c|c|c}
\hline Procedures & $\boldsymbol{\Delta}$ (post-pre) & CI 95\% \\
\hline Conservative & $-2.02^{*}$ & $(-2.65--1.49)$ \\
\hline Infiltration & $-1.63^{*}$ & $(-2.34--0.93)$ \\
\hline Surgery & $-3.77^{* *}$ & $(-4.29--3.24)$ \\
\hline
\end{tabular}

${ }^{*} \mathrm{P}<0.001$ in relation to the baseline values. ${ }^{*} \mathrm{P}<0.001$ in relation to the other procedures. The deltas are adjusted using the baseline VAS values as covariable; thus the adjusted baseline values are VAS pre $=6.83$

Table 5. Delta of difference in the Roland Morris for the Infiltration, Conservative and Surgical procedures.

\begin{tabular}{c|c|c}
\hline Procedures & $\boldsymbol{\Delta}$ (post-pre) & Cl 95\% \\
\hline Conservative & $-4.00^{*}$ & $(-5.28--2.71)$ \\
\hline Infiltration & $-2.41^{*}$ & $(-4.00--0.85)$ \\
\hline Surgery & $-8.20^{* \#}$ & $(-9.38--7.02)$
\end{tabular}

${ }^{*} \mathrm{P}<0.001$ in relation to the baseline values. ${ }^{*} \mathrm{P}<0.001$ in relation to the other procedures. The deltas are adjusted using the baseline Roland Morris values as covariable; thus the adjusted baseline values are Morris pre $=13.67$.

Table 6. Delta of difference in the EQ-5D for the Infiltration, Conservative and Surgical procedures.

\begin{tabular}{c|c|c}
\hline Procedures & $\boldsymbol{\Delta}$ (post-pre) & Cl 95\% \\
\hline Conservative & $0.26^{*}$ & $(0.19-0.34)$ \\
\hline Infiltration & $0.19^{*}$ & $(0.11-0.28)$ \\
\hline Surgery & $0.40^{* *}$ & $(0.34-0.47)$ \\
\hline
\end{tabular}

${ }^{*} P<0.001$ in relation to the baseline values. ${ }^{\#} P<0.001$ in relation to the other procedures. The deltas are adjusted using the baseline $\mathrm{EQ}-5 \mathrm{D}$ values as covariable; thus the adjusted baseline values are $E Q-5 D$ pre $=0.40$

Table 7. Absolute and relative frequency of the degenerative changes in the vertebral endplate according to the Modic classification.

\begin{tabular}{c|c|c|c}
\hline & Absolute frequency & Relative frequency (\%) & IC (95\%) \\
\hline Modic 0 & 116 & 48.33 & $(42.04-54.68)$ \\
\hline Modic I & 70 & 29.17 & $(23.74-35.26)$ \\
\hline Modic II & 54 & 22.50 & $(17.64-28.25)$ \\
\hline
\end{tabular}

Table 1. Delta of difference in the VAS for the Modic classifications in the Conservative, Infiltration and Surgical groups

\begin{tabular}{|c|c|c|c|c|c|c|}
\hline & $\begin{array}{c}\Delta \\
\text { (post-pre) }\end{array}$ & CI $95 \%$ & $\begin{array}{c}\Delta \\
\text { (post-pre) }\end{array}$ & CI $95 \%$ & $\begin{array}{c}\Delta \\
\text { (post-pre) }\end{array}$ & Cl $95 \%$ \\
\hline Modic 0 & -1.20 & $(-2.13--0.28)$ & -2.25 & $(-3.29--1.21)$ & -3.96 & $(-4.63--3.29)$ \\
\hline Modic II & -1.95 & $(-3.03--0.87)$ & -0.22 & $(-2.08-1.63)$ & -5.14 & $(-6.22--4.05)$ \\
\hline
\end{tabular}

The deltas are adjusted using the baseline VAS values as covariable.

Table 2. Delta of difference in the Roland Morris for the Modic classifications in the Conservative, Infiltration and Surgical groups.

\begin{tabular}{c|c|c|c|c|c|c|c}
\hline & $\begin{array}{c}\Delta \\
\text { (post-pre) }\end{array}$ & Cl 95\% & $\begin{array}{c}\Delta \\
\text { (post-pre) }\end{array}$ & Cl 95\% & $\begin{array}{c}\boldsymbol{\Delta} \\
\text { (post-pre) }\end{array}$ & \multicolumn{3}{c}{ Cl 95\% } \\
\hline & \multicolumn{2}{|c|}{ Conservative } & \multicolumn{2}{|c}{ Infiltration } & $(-10.91--7.61)$ \\
\hline Modic 0 & -1.87 & $(-3.81-0.06)$ & -3.33 & $(-5.23-1.42)$ & -9.26 \\
\hline Modic I & -3.24 & $(-5.33--1.14)$ & -1.49 & $(-4.61-1.62)$ & -9.67 & $(-11.83--7.50)$ \\
\hline Modic II & -2.74 & $(-5.00--0.47)$ & -0.63 & $(-2.79-4.06)$ & -10.00 & $(-12.60--7.38)$ \\
\hline
\end{tabular}

The deltas are adjusted using the baseline Roland Morris values as covariable.

Table 3. Delta of difference in the EQ-5D for Modic classifications in the Conservative, Infiltration and Surgical groups.

\begin{tabular}{c|c|c|c|c|c|c|c}
\hline & $\begin{array}{c}\Delta \\
\text { (post-pre) }\end{array}$ & Cl 95\% & $\begin{array}{c}\Delta \\
\text { (post-pre) }\end{array}$ & Cl 95\% & \multicolumn{1}{c|}{$\begin{array}{c}\Delta \\
\text { (post-pre) }\end{array}$} & \multicolumn{3}{c}{ Cl 95\% } \\
\hline & \multicolumn{2}{|c|}{ Conservative } & \multicolumn{2}{|c}{ Infiltration } & \multicolumn{4}{c}{ Surgical } \\
\hline Modic 0 & 0.13 & $(0.01-0.25)$ & 0.27 & $(0.15-0.39)$ & 0.50 & $(0.42-0.58)$ \\
\hline Modic I & 0.18 & $(0.06-0.31)$ & 0.08 & $(-0.14-0.30)$ & 0.59 & $(0.47-0.70)$ \\
\hline Modic II & 0.12 & $(-0.01-0.25)$ & -0.09 & $(-0.30-0.13)$ & 0.47 & $(0.34-0.60)$ \\
\hline
\end{tabular}

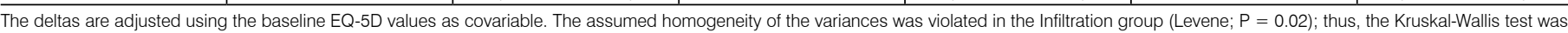
used for this group. 
18 to $62 \%$ in patients with low back pain, but with different distribution for each type. ${ }^{14-16}$ Types I and II are the most prevalent, but there is debate about which one would be the most prevalent in symptomatic patients. ${ }^{17}$ What is known is that changes in the endplate signal become more prevalent with increasing age and weight, and in males. ${ }^{17}$

These changes have three main characteristics in the lumbar spine. Modic et al. observed that the most common VESC topography was L4-L5 and L5-S1. ${ }^{3}$ The distribution of type I and type II changes is in the anterior third of the vertebral endplate and those of type II are more common in the upper vertebral endplate than in the lower vertebral endplate. ${ }^{4}$ Chung et al. observed that asymptomatic VESCs are located in the higher levels (upper endplate of L3 and L4) and anteriorly, while symptomatic VESCs are in the lower levels (between levels L4-L5 and L5-S1). ${ }^{18}$

Due to the evolutionary nature of the vertebral endplate signal, the type I change is considered the initial and most active stage of the process, ${ }^{4}$ and the presence of high levels of $\mathrm{C}$-reactive protein, TNF-a, IL-6, IL-8 and PGE ${ }_{2}{ }^{19,20}$ Weishaupt et al. showed that type II Modic changes are present in symptomatic individuals and can be as limiting as those of type I, even though this is considered a quiescent and less painful stage. ${ }^{21}$

Only a portion of the VESC cases (20\%) is correlated with an anatomopathological diagnosis such as infection, degenerative or immunological causes. ${ }^{17}$ Several studies have tried to correlate VESC with low back pain. Kuisma et al. observed a greater association between type I VESC at the L5-S1 level with low back pain than other associations. ${ }^{22}$ In a case study with a 5-year follow-up, Carragee et al. showed that a moderate or severe VESC was little associated with a poor prognosis in patients with persistent low back pain. ${ }^{23}$ Another study reported that type I VESC is not a risk factor for low back pain in their study of 131 asymptomatic patients, depression being the only predictive factor of lumbar pain, while from the imaging findings, central stenosis and contact with the nerve root showed some association, but without statistical significance. ${ }^{24}$

Studies have reported that VESC may also be present, but less prevalent, in asymptomatic individuals. A study conducted with 228 workers in the north of Finland reported the presence of Modic changes in asymptomatic individuals to be 11\% (type I, 3\%; type II,
$5 \%$; type III, 3\%). ${ }^{21}$ Chung et al. investigated the presence of Modic in 59 asymptomatic patients and observed 8 with type I, 15 with type II in 590 lumbar vertebral endplates, the type II changes being observed in the older individuals. ${ }^{18}$

The studies confirm that there is a relationship between VESC and discogenic pain, but there are controversies about the relationship between signal changes and results following clinical intervention or new low back pain. ${ }^{17}$ These controversies may stem from differences in the inclusion criteria, methodology and sample size, as well as from differences in patient treatment adherence, social and psychological factors. ${ }^{17}$

A study conducted with 178 patients who underwent microdiscectomy observed that patients with type I VESC had less but significant improvement 12 months after surgery than the other types, but without statistical significance. ${ }^{25}$ Tobacco use was the only significant factor. ${ }^{25} \mathrm{~A}$ study with a 10 -year follow-up, conducted with 70 patients did not observe any significance in pain intensity, degree of disability, need for medical or surgical treatment $(P>0.05)$ in type I, type II or type III Modic patients, even between patients with and without changes to the vertebral endplate signal $(P>0.05) .{ }^{26}$

\section{CONCLUSION}

This study is in line with the literature, failing to associate VESC with a prognosis in patients treated for low back pain and lumbosciatica. Patients without VESC with disabling pain were also observed, showing that this change is not specific to low back pain.

There are several limitations in the study due to the small sample, its retrospective nature, and one-year follow-up.

\section{ACKNOWLEDGEMENTS}

The team thanks the patients for providing the research data and the team involved for its dedication, teamwork, and support, especially the employees of the HIAE Locomotor Program.

All authors declare no potential conflict of interest related to this article.

\section{REFERENCES}

1. Vroomen PCAJ, de Krom MCTFM, Slofstra PD, Knottnerus JA. Conservative Treatment of Sciatica: A Systematic Review. J Spinal Disord. 2000;13(6):463-9.

2. Katz JN. Lumbar Disc Disorders and Low-Back Pain: Socioeconomic Factors and Consequences. 2006;88 Suppl 2:21-4

3. Modic MT, Steinberg PM, Ross JS, Masaryk TJ, Carter JR. Degenerative disk disease: assessment of changes in vertebral body marrow with MR imaging. Radiology. 1988;166(1 Pt 1):193-9.

4. Modic MT, Masaryk TJ, Ross JS, Carter JR. Imaging of degenerative disk disease. Radiology. 1988;168(1):177-86

5. Jensen TS, Karppinen J, Sorensen JS, Niinimäki J, Leboeuf-Yde C. Vertebral endplate signal changes (Modic change): a systematic literature review of prevalence and association with non-specific low back pain. Eur Spine J. 2008;17(11):1407-22.

6. Kang SH, Choi SH, Seong NJ, Ko JM, Cho ES, Ko KP. Comparative study of lumbar magnetic resonance imaging and myelography in young soldiers with herniated lumbar disc. J Korean Neurosurg Soc. 2010;48(6):501-5.

7. Borenstein DG, O'Mara JW Jr, Boden SD, Lauerman WC, Jacobson A, Platenberg C, et al. The Value of Magnetic Resonance Imaging of the Lumbar Spine to Predict Low-Back Pain in Asymptomatic Subjects a seven-year follow-up study. J Bone Joint Surg Am. 2001:83(9):1306-11.

8. Fardon DF, Milette PC. Nomenclature and Classification of Lumbar Disc Pathology. Recommendations of the Combined task Forces of the North American Spine Society, American
Society of Spine Radiology, and American Society of Neuroradiology. Spine (Phila Pa 1976). 2001:26(5):93-113.

9. Boden SD, Davis DO, Dina TS, Patronas NJ, Wiesel SW. Abnormal Magnetic-Resonance Scans of the Lumbar Spine in Asymptomatic Subjects A prospective investigation. J Bone Joint Surg Am. 1990;72(3):403-8.

10. Parker SL, Godil SS, Shau DN, Mendenhall SK, McGirt MJ. Assessment of the minimum clinically important difference in pain, disability, and quality of life after anterior cervical discectomy and fusion. J Neurosurg Spine. 2013;18(2):154-60.

11. Nusbaum L, Natour J, Ferraz MB, Goldenberg J. Translation, adaptation and validation of the Roland-Morris questionnaire - Brazil Roland-Morris. Braz J Med Biol Res. 2001;34(2):203-10.

12. Jensen MC, Brant-Zawadzki MN, Obuchowski N, Modic MT, Malkasian D, Ross JS. Magnetic Resonance Imaging of the Lumbar Spine in People without Back Pain. N Engl J Med. 1994:331(2):69-73.

13. Cavanaugh JM, Ozaktay AC, Yamashita T, Avramov A, Getchell TV, King Al. Mechanisms of low back pain: a neurophysiologic and neuroanatomic study. Clin Orthop Relat Res. 1997;(335):166-80.

14. Albert HB, Kjaer P, Jensen TS, Sorensen JS, Bendix T, Manniche C. Modic changes, possible causes and relation to low back pain. Med Hypotheses. 2008;70(2):361-8.

15. Karchevsky M, Schweitzer ME, Carrino JA, Zoga A, Montgomery D, Parker L. Reactive endplate marrow changes: a systematic morphologic and epidemiologic evaluation. Skeletal Radiol. 2005;34(3):125-9. 
16. Mitra D, Cassar-Pullicino VN, Mccall IW. Longitudinal study of vertebral type-1 end-plate changes on MR of the lumbar spine. Eur Radiol. 2004;14(9):1574-81.

17. Zhang YH, Zhao CQ, Jiang LS, Chen XD, Dai LY. Modic changes: a systematic review of the literature. Eur Spine J. 2008:17(10):1289-99.

18. Chung CB, Vande Berg BC, Tavernier T, Cotten A, Laredo JD, Vallee C, et al. End plate marrow changes in the asymptomatic lumbosacral spine: frequency, distribution and correlation with age and degenerative changes. Skeletal Radiol. 2004:33(7):399-404.

19. Ohtori S, Inoue G, Ito T, Koshi T, Ozawa T, Doya H, et al. Tumor Necrosis Factor-Immunoreactive Cells and PGP 9.5-Immunoreactive Nerve Fibers in Vertebral Endplates of Patients With Discogenic Low Back Pain and Modic Type 1 or Type 2 Changes on MRI. Spine (Phila Pa 1976). 2006:31(9):1026-31.

20. Burke JG, Watson RWG, McCormack D, Dowling FE, Walsh MG, Fitzpatrick JM. Intervertebral discs which cause low back pain secrete high levels of proinflammatory mediators. J Bone Joint Surg Br. 2002;84(2):196-201.

21. Weishaupt $D$, Zanetti M, Hodler J, Boos N. MR imaging of the lumbar spine: prevalence of intervertebral disk extrusion and sequestration, nerve root compression, end plate abnormalities, and osteoarthritis of the facet joints in asymptomatic volunteers. Radiology. 1998:209(3):661-6.

22. Kuisma M, Karppinen J, Niinimäki J, Ojala R, Haapea M, Heliövaara M, et al. Modic Changes in Endplates of Lumbar Vertebral Bodies. Spine (Phila Pa 1976). 2007;32(10):1116-22.

23. Carragee EJ, Alamin TF, Miller JL, Carragee JM. Discographic, MRI and psychosocial determinants of low back pain disability and remission: a prospective study in subjects with benign persistent back pain. Spine J. 2005;5(1):24-35.

24. Jarvik JG, Hollingworth W, Heagerty PJ, Haynor DR, Boyko EJ, Deyo RA. Three-year incidence of low back pain in an initially asymptomatic cohort: clinical and imaging risk factors. Spine (Phila Pa 1976). 2005;30(13):1541-8; discussion 1549.

25. Sørlie A, Moholdt V, Kvistad KA, Nygaard ØP, Ingebrigtsen T, Iversen T, et al. Modic type I changes and recovery of back pain after lumbar microdiscectomy. Eur Spine J. 2012:21(11):2252-8.

26. Romero-Muñoz L, Barriga-Martín A, Segura-Fragoso A, Martín-González C. ¿Supone la presencia de cambios Modic en pacientes con dolor lumbar crónico una peor evolución clínica y una mayor posibilidad de precisar cirugía? Evolución a 10 años. Rev Esp Cir Ortop Traumatol. 2018;62(4):274-81. 